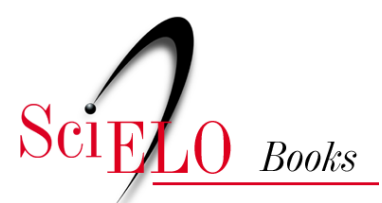

\title{
4. Dos Quatro Humores às Quatro Bases
}

\author{
Joffre Marcondes de Rezende
}

\section{SciELO Books / SciELO Livros / SciELO Libros}

REZENDE, J. M. Dos Quatro Humores às Quatro Bases. In: À sombra do plátano: crônicas de história da medicina [online]. São Paulo: Editora Unifesp, 2009, pp. 49-53. História da Medicina series, vol. 2. ISBN 978-85-61673-63-5. https://doi.org/10.7476/9788561673635.0005.

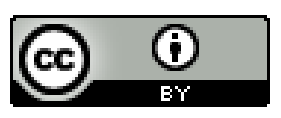

All the contents of this work, except where otherwise noted, is licensed under a Creative Commons Attribution 4.0 International license.

Todo o conteúdo deste trabalho, exceto quando houver ressalva, é publicado sob a licença Creative Commons Atribição 4.0.

Todo el contenido de esta obra, excepto donde se indique lo contrario, está bajo licencia de la licencia Creative Commons Reconocimento 4.0. 


\section{Dos Quatro Humores às Quatro Bases}
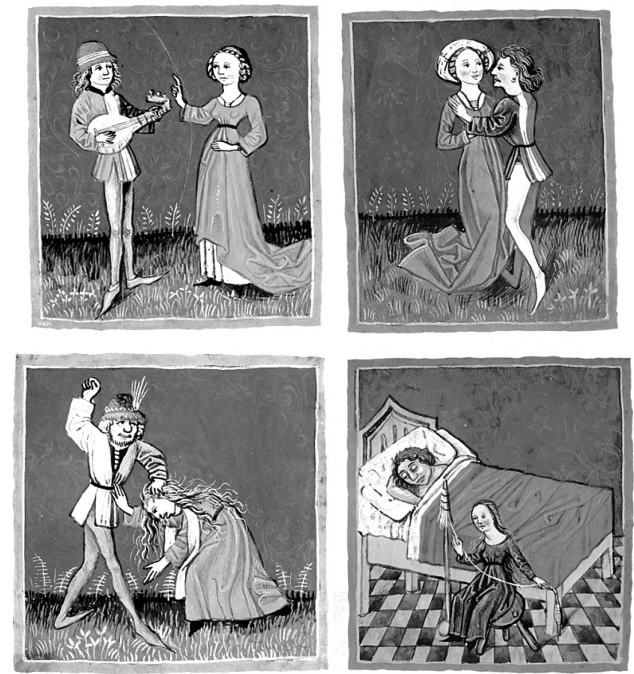

Os quatro temperamentos.

$\mathrm{D}$ esde a Antiguidade e em várias civilizações, o número quatro tem um simbolismo especial: o da plenitude, da totalidade, da abrangência, da universalidade. Expressa, ao mesmo tempo, o concreto, o visível, o aparente, o criado, ao contrário do número três, que espelha o transcendental, o espiritual, o abstrato, o divino. Nas palavras de Platão: “O ternário é o número das ideias; o quaternário, o da realização das ideias”.

Esta concepção parece radicar-se no inconsciente coletivo, porquanto o mesmo simbolismo aparece em todas as civilizações, inclusive entre povos indígenas e tribos africanas.

O número quatro liga-se ao quadrado e à cruz, que, juntamente com o círculo e o centro, constituem os quatro símbolos fundamentais da humanidade.

No bramanismo hindu, fala-se nos quatro domínios do universo, que correspondem às quatro partes de Brama.

$\mathrm{Na}$ Bíblia, o número quatro aparece com grande frequência, do Gênesis ao Apocalipse. O nome de Deus em hebraico se escreve com quatro letras, assim como o do primeiro homem, Adão. São quatro os rios do Éden que 
delimitam o espaço habitável. Na visão de Ezequiel aparecem quatro animais com quatro faces e quatro asas. A cada passagem do Apocalipse surge o número quatro: são quatro cavaleiros, quatro pragas principais, quatro anjos, quatro emblemas das tribos de Israel, quatro muralhas de Jerusalém, quatro cantos da Terra.

O cruzamento de um meridiano com um paralelo divide a Terra em quatro partes. Por isso encontramos na história referências aos quatro mares, quatro reinos, quatro ventos, quatro partes do mundo. Quatro são os pontos cardiais: norte, sul, leste, oeste; quatro são as estações do ano: verão, outono, inverno, primavera; quatro são as fases da lua: cheia, minguante, nova e crescente; quatro são as fases da vida: infância, juventude, maturidade e velhice.

$\mathrm{Na}$ psicanálise o número quatro se revela no seu simbolismo. Jung reconhece no quaternário o arquétipo da totalidade dos processos psíquicos conscientes e inconscientes e enumera quatro funções fundamentais da consciência: o pensamento, o sentimento, a intuição e a sensação (Chevalier e Gheerbrant, 1989), e Mira y Lopez se refere aos quatro gigantes da alma: o medo, a ira, o amor e o dever.

É natural, portanto, que os filósofos gregos da escola pitagórica tenham imaginado o universo formado por quatro elementos: terra, ar, fogo e água, dotados de quatro qualidades, opostas aos pares: quente e frio, seco e úmido.

A transposição da estrutura quaternária universal para o campo da biologia deu origem à concepção dos quatro humores do corpo humano. $\mathrm{O}$ conceito de humor (khymós, em grego), na escola hipocrática, era de uma substância existente no organismo, necessária à manutenção da vida e da saúde. Inicialmente, fala-se em número indeterminado de humores. Posteriormente, verifica-se a tendência de simplificação, reduzindo-se o número de humores para quatro, com seu simbolismo totalizador: o sangue, a fleuma, a bile amarela e a bile negra, conforme se lê no livro Peri physion anthropoy ( $D a$ Natureza do Homem):

O corpo do homem contém sangue, fleuma, bile amarela e bile negra - esta é a natureza do corpo, através da qual adoece e tem saúde. Tem saúde, precisamente, quando estes humores são harmônicos em proporção, em propriedade e em quantidade, e sobretudo quando são misturados. O homem adoece quando há falta ou 
excesso de um desses humores, ou quando ele se separa no corpo e não se une aos demais. (Cairus, I999)

Admite-se que a crença na existência de uma bile negra tenha sido fruto da observação clínica nos casos de hematêmese, melena e hemoglobinúria.

Segundo a doutrina dos quatro humores, o sangue é armazenado no fígado e levado ao coração, onde se aquece, sendo considerado quente e úmido; a fleuma, que compreende todas as secreções mucosas, provém do cérebro e é fria e úmida por natureza; a bile amarela é secretada pelo fígado e é quente e seca, enquanto a bile negra é produzida no baço e no estômago e é de natureza fria e seca.

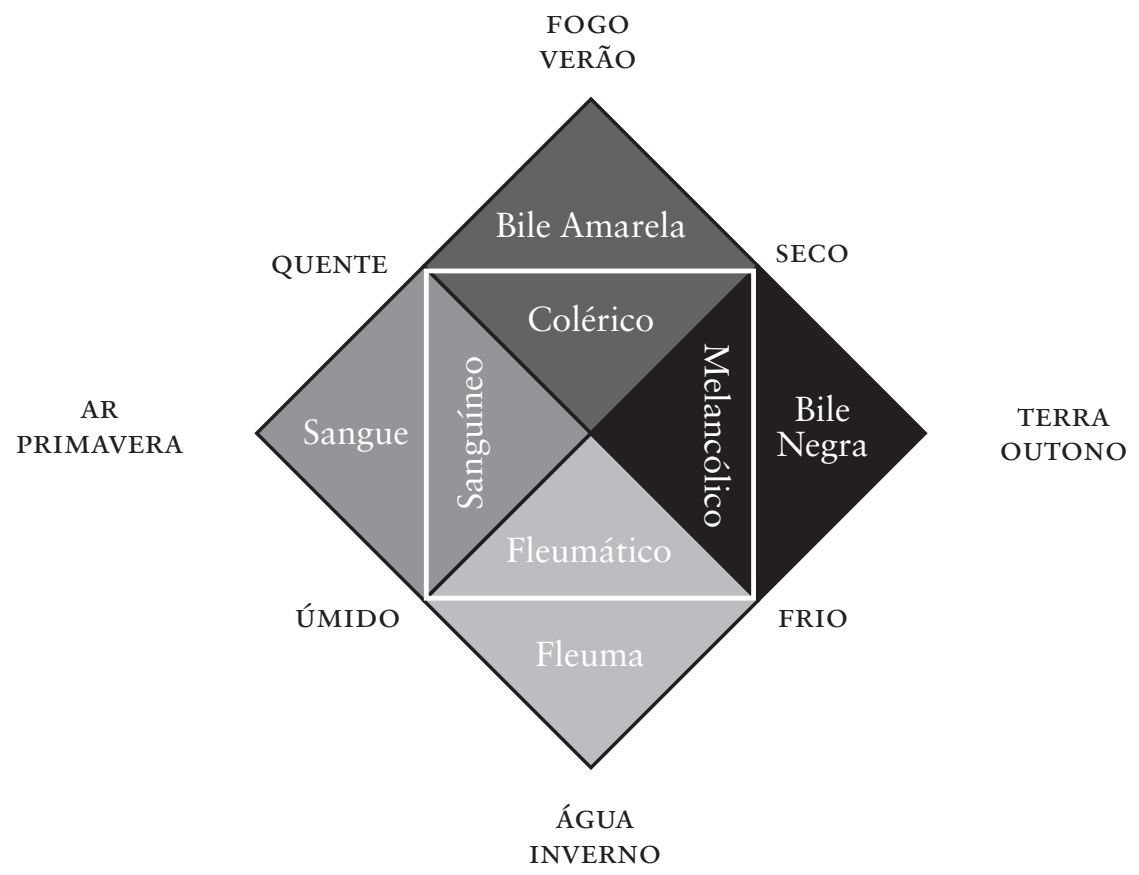

O número quatro no macro e no microcosmo.

A doutrina dos quatro humores encaixava-se perfeitamente na concepção filosófica da estrutura do universo. Estabeleceu-se uma correspondência entre os quatro humores com os quatro elementos (terra, ar, fogo e água), com as quatro qualidades (frio, quente, seco e úmido) e com as quatro estações do ano (inverno, primavera, verão e outono). 
O estado de saúde dependeria da exata proporção e da perfeita mistura dos quatro humores, que poderiam alterar-se por ação de causas externas ou internas. $\mathrm{O}$ excesso ou deficiência de qualquer dos humores, assim como o seu isolamento ou miscigenação inadequada, causariam as doenças com o seu cortejo sintomático.

Segundo a concepção hipocrática da patologia humoral, quando uma pessoa se encontra enferma, há uma tendência natural para a cura; a natureza (Physis) encontra meios de corrigir a desarmonia dos humores (discrasia), restaurando o estado anterior de harmonia (eucrasia).

Este processo se realiza em três etapas nas doenças agudas: apepsia, pepsia (cocção) e crisis. A crisis tem tendência a ocorrer em dias certos, o que levou Hipócrates a estudar os dias críticos de várias enfermidades (Castiglioni, I947, pp. I9I-I92).

A recuperação do enfermo acompanha-se da eliminação do humor excedente ou alterado. O médico pode auxiliar as forças curativas da natureza, retirando do corpo o humor em excesso ou defeituoso, a fim de restaurar o equilíbrio. Com esta finalidade, surgiram os quatro principais métodos terapêuticos: sangria, purgativos, eméticos e clisteres.

Galeno, no século II d.C., com o prestígio de sua autoridade, revitalizou a doutrina humoral e ressaltou a importância dos quatro temperamentos, conforme o predomínio de um dos quatro humores: sanguíneo, fleumático, colérico (de cholé, bile), melancólico (de melános, negro + cholé, bile). Colérico, portanto, é aquele que tem mais bile amarela, e melancólico, o que tem mais bile negra. Transfere-se, desse modo, para o comportamento das pessoas, a noção de equilíbrio e harmonia dos humores (Diepgen, I932, p. 77). As expressões "bom humor", "mau humor", "bem-humorado", "mal-humorado" são reminiscências dos conceitos de eucrasia e discrasia.

A doutrina da patologia humoral guiou a prática médica por mais de dois mil anos e só começou a perder terreno com a descoberta da estrutura celular dos seres vivos graças ao desenvolvimento da microscopia. Os órgãos e os tecidos deixaram de ser considerados como massas consistentes resultantes da solidificação dos humores e passaram a ser vistos como aglomerados de células individuais, adaptadas à natureza e função de cada órgão (Virchow, I 859). Coube a Rudolf Virchow (I82I-I902) estabelecer as bases da nova patologia, fundamentada nas alterações celulares causadas 
pelas doenças. A milenar doutrina da patologia humoral foi substituída pela patologia celular, o que representou um marco na evolução da teoria e da prática da medicina.

Ao mesmo tempo, o estudo da embriologia e do processo de divisão celular levou à descoberta das estruturas intracelulares, em especial do núcleo, dos cromossomas, dos genes, e, finalmente, do DNA (ácido desoxirribonucleico), substância primordial de todas as formas de vida, aquela que encerra o código genético, define os caracteres hereditários e assegura a continuidade das espécies.

A identificação cristalográfica e química do DNA permitiu identificar a sua estrutura helicoidal e pode ser considerada um dos feitos mais notáveis da pesquisa biológica.

$\mathrm{Na}$ complexidade e diversidade das diferentes formas de vida, uma surpresa: o ressurgimento do número quatro nas quatro bases que integram o DNA: adenina, timina, guanina e citosina. Todos os seres vivos - animais, plantas, bactérias e muitos vírus - são o resultado de diferentes sequenciamentos e combinações dessas quatro bases na dupla hélice do DNA. E as quatro bases, por sua vez, são formadas de quatro elementos químicos: carbono, oxigênio, hidrogênio e nitrogênio.

No dizer do prof. Spyros Marketos, presidente da Fundação Internacional Hipocrática de Cós, o modelo quaternário da escola hipocrática mostrou-se compatível com as recentes descobertas da biologia molecular (Marketos, I996, pp. 6I-7I).

\section{Referências Bibliográficas}

Cairus, H. "Da Natureza do Homem”. História, Ciência, Saúde-Manguinhos, vol. 6, no 2, jul.-out. I999.

Castiglioni, A. A História da Medicina. São Paulo, Cia. Editora Nacional, I947.

Chevalier, J. \& Gheerbrant, A. Dicionário de Símbolos. Rio de Janeiro, José Olympio, I989.

Diepgen, P. Historia de la Medicina. $2^{\underline{a}}$ ed., Barcelona, Labor, I932.

Marketos, S. G. "Hippocratic Medicine and Philosophy at the Turn of the 20 th Century".

Proceedings of the Ist International Medical Olympiad, vol. I, I996.

Virchow, R. L. K. Die cellularpathologie. Berlin, A. Hirschwald, I 859. 